Aletria, Belo Horizonte, v. 31, n. 2, p. 23-43, 2021

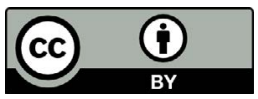

\title{
Robinson Crusoe in the South Atlantic
}

\section{Robinson Crusoé no Atlântico Sul}

\author{
Sandra Guardini Teixeira Vasconcelos \\ Universidade de São Paulo (USP), São Paulo, São Paulo / Brasil \\ sgtvasco@usp.br \\ https://orcid.org/0000-0002-7222-5802
}

\begin{abstract}
This article explores the Brazilian episode in Daniel Defoe's Robinson Crusoe (1719). It argues that this episode not only plays a pivotal role in the novel's plot, as it ends up in disaster and Crusoe's shipwreck, but also has historical significance once it offers a glimpse of the transnational and transcontinental nature of the slave trade in the South Atlantic, involving Portugal, England and Brazil.
\end{abstract}

Keywords: Robinson Crusoe; Daniel Defoe; English novel; slave trade; slavery; colonialism.

Resumo: Este artigo explora o episódio brasileiro em Robinson Crusoe (1719), de Daniel Defoe. Argumenta-se que esse episódio não apenas desempenha um papel fundamental no enredo do romance, pois termina em desastre e no naufrágio de Crusoe, mas também tem importância histórica, uma vez que permite vislumbrar a natureza transnacional e transcontinental do tráfico negreiro no Atlântico Sul, envolvendo Portugal, Inglaterra e Brasil.

Palavras-chave: Robinson Crusoe; Daniel Defoe; romance inglês; tráfico negreiro; escravidão; colonialismo.

In its 300 years, Robinson Crusoe has had a global reach in more ways than one: it has had countless editions, has been translated into numerous languages, has been adapted and imitated, and has also made history by providing successors with a distinctive narrative paradigm. 
By the same token, it has been famously read as a castaway narrative, an example of fictional realism, or a tale of self-sufficiency and spirit of enterprise and conquest. In this article, however, I would like to address still another dimension of its globality and explore the novel's rendering of a crucial moment in the history of the South Atlantic, and Defoe's protagonist's participation in it. Though playing a seemingly minor role in the overall narrative of Crusoe's adventures and social and economic advancement, the episodes I would like to examine more closely here have a significant bearing on and represent tipping points in the protagonist's fate and future. Defoe's Robinson Crusoe can be brought under the aegis of the transnational due to its direct or indirect links with the South Atlantic world and the transnational nature of the interests involved in the one economic activity that made Africa into "the crossroads of the colonial trade routes" (HULME, 1992, p. 185). The machinery of the slave trade and traffic, and the exploitation of African territories and slave labour, pervade the novel one way or another, as part of its development and rationale. My main concern here is the preisland section of the novel and Crusoe's adventures in the South Atlantic - primarily his "Voyage to the Brasils" and arrival at the "Bay de Todos los Santos" - and their bearing on the encounter with Friday on the island.

Robinson Crusoe foregrounds as its protagonist a young man, "the third Son of the Family, and not bred to any Trade", whose "middle state, or what might be called the upper station of low life" (DEFOE, 2008, p. 5-6) should make him content, according to his father. His urge for adventure, however, urges him to leave home and roam the seas in search of fortune. Defoe takes his main character to distant lands and, by withdrawing him from the domestic and national space, expands the geographical boundaries of the novel genre to include the experience of English colonialism. Seen as the embodiment of economic individualism by Ian Watt, in his classic The Rise of the Novel, Defoe's characters are faced with the need to survive and are driven by the wish to prosper in a world where the commercial values of competition rule. Free from familial or emotional ties - "But I know that with Money in the Pocket one is at home any where" is Moll Flanders's conclusion and motto (DEFOE, 1973, p. 139) -, his characters make the wide world their home, in their pursuit of self-fulfilment.

The epitome of the capitalist entrepreneur, according to Ian Watt, an inspiration for those displaced by urban capitalism and for empire- 
builders, Robinson Crusoe has new territories to conquer. By removing his character from England, Defoe suggested new directions for the novel, which included new lands to explore and stretched the borders of the familiar, beyond the domestic and what it meant to be English. The novel's appeal seems obvious:

Follow the call of the wide open places, discover an island that is desert only because it is barren of owners or competitors, and there build your personal Empire with the help of a Man Friday who needs no wages and makes it much easier to support the white man's burden (WATT, 1983, p. 96).

Crusoe's adventurous spirit and urge bring him to the transcontinental space of the South Atlantic, an a-territorial expanse where slave-trade networks linked Europe, Africa, and the Americas. Very early on in the novel, after his first disastrous experience at sea, Crusoe sets out on a voyage to Guinea, for many a euphemism for a slave-trading expedition, which he joins as a private passenger (not as a sailor) whose purpose is to trade trifles for gold (he will later remark that his success set him up 'for a Guiney trader'). His second voyage is less successful and, attacked by pirates, Crusoe and the crew are made prisoners and taken to Salé, on the Moroccan coast. Himself made into a slave, he endures two years of captivity before he manages to escape, taking the young Moorish boy Xury with him. Nonetheless, his own experience of enslavement and Xury's help, companionship, and loyalty do not prevent Crusoe from selling him afterwards to the Portuguese captain who rescues them. He swiftly overcomes any misgivings against the captain's offer and puts behind him any acknowledgement of the boy's agency in their escape from the perils on the Barbary Coast. Their previous enslaved condition does not make them equals. While Xury will remain in indentured servitude for ten years, Crusoe as a white European receives a very generous treatment from the captain, who leaves him safe and sound on the shore "in the Brasils" and helps him set up an estate.

Crusoe's account of his Brazilian experience does not exceed six pages. However, it is pivotal in the narrative because of the consequences that ensue. The episode shows us the protagonist living with "a good honest man" who had a sugar plantation, where he learns how to plant and make sugar. As a result of his acquaintance with this new activity, 
[...] seeing how well the Planters liv'd, and how they grew rich suddenly, I resolv'd, if I could get License to settle there, I would turn Planter among them, resolving in the mean time to find out some Way to get my Money which I had left in London remitted to me. To this Purpose getting a kind of a Letter of Naturalization, I purchased as much Land that was Uncur'd, as my Money could reach, and form'd a Plan for my Plantation and Settlement, and such a one as might be suitable to the Stock which I proposed to my self to receive from England. (DEFOE, 2008, p. 31)

Having suffered the vicissitudes of enslavement himself does not stop Crusoe from becoming a slave-owner once he starts his own plantation and settlement in Bahia:

Neither was this all; but my Goods being all English Manufactures, such as Cloath, Stuffs, Bays, and things particularly valuable and desirable in the Country, I found means to sell them to a very great Advantage; so that I might say, I had more than four times the Value of my first Cargo, and was now infinitely beyond my poor Neighbour, I mean in the Advancement of my Plantation; for the first thing I did, I bought me a Negro Slave, and an European Servant also - I mean another besides that which the Captain brought me from Lisbon. (DEFOE, 2008, p. 33)

After four years, rather than being content with thriving and prospering Crusoe becomes restless again, and ambition gets the better of him when he sees the opportunity of rising from mere tobacco planter to sugar mill owner. In exchanges with acquaintances and friends, when giving them accounts of his voyages he remarks how easy it had been to purchase "not only Gold, Guinea Grains, Elephants Teeth, \&c, but Negroes for the Service of the Brasils, in great numbers" (DEFOE, 2008, p. 34):

They listened always very attentively to my Discourses on these Heads, but especially to that Part which related to the buying Negroes, which was a Trade at that time not only nor far entred into, but as far as it was, had been carried on by the Assiento's, or Permission of the Kings of Spain and Portugal, and engross'd in the Publick, so that few Negroes were bought, and those excessive dear. (DEFOE, 2008, p. 35) 
It is then that Crusoe is approached by some merchants and planters, who propose he makes yet another voyage "to bring the Negroes on Shoar privately", with the promise they would "divide them among their own plantations" (DEFOE, 2008, p. 35) and give him his equal share. Unable to resist the offer, Crusoe ventures yet again at sea. This is a decision that he will regret later, with the benefit of hindsight:

$[\ldots]$ had I used half as much Prudence to have look'd into my own Intrest, and have made a Judgement of what I ought to have done, and not to have done, I had certainly never gone away from so prosperous an Undertaking, leaving all the probable Views of a thriving Circumstance, and gone upon a Voyage to Sea, attended with all its common Hazards; to say nothing of the Reasons I had to expect particular Misfortunes to my self. (DEFOE, 2008, p. 36)

This reflection anticipates what is to come about. As we well know, his second, even more, catastrophic shipwreck occurs when he sets out from Bahia for the coast of Guinea and the ship is hit by a tornado or hurricane, thrown off course and driven "out of the very Way of all humane Commerce" (DEFOE, 2008, p. 37) by a second storm. Crusoe's inclination to wander ends in disaster once again and the outcome of the Brazilian episode for him is a deserted island where he will have to resort to pragmatism and instrumental rationality in order to survive for twenty eight years.

What could be considered as passing references to slavery in a narrative that centres on Crusoe's life on the island takes on a new meaning when read in the light of Daniel Defoe's ideas on trade and the colonial system, and of the connections between metropole and colony in the age of mercantile capitalism. Apart from implying the economic relationship between Brazil and Africa, and the importance of the expeditions bound for Africa, the Brazilian episode and other mentions of slavery in the novel confirm Defoe's position regarding the need for the slave trade: "'The African trade is absolutely necessary to be supported... Negroes are as essential to the Sugar Works at Barbados, Jamaica ... as Wind is to the Ships that bring it home."' (DEFOE apud DABYDEEN, 1983 , p. 4). Though this opinion was being aired in an article in his Review in 1713, it seems to hold true in relation to Crusoe's own view in the novel. It is Patrick Keane's claim that even if Defoe expressed divided feelings concerning the slave trade in some of his writings, he 
was a strong supporter of the trade in his essays, mainly those published in the Review between 1709 and $1713 .{ }^{1}$ He believed that the slave trade was a respectable business, had stocks from two companies engaged in the traffic, and considered it essential to British colonialism (KEANE, 1997). Even though the events in the Brazilian episode take place in the 1650s ("I went on Board in an evil Hour, the 1 st of Sept. 1659" (DEFOE, 2008, p. 36)), one would be right to think that Crusoe is an upholder of the same ideas Defoe was discussing in the early eighteenth century.

In sum, Crusoe's decision to board the ships bound for the coast of Africa, his trials and tribulations there, and his activities in Brazil are inextricably entangled with slavery and the slave trade, which, despite their pivotal role in the protagonist's Atlantic adventures, have been generally overlooked as the points of origin in the novel. It is Daniel Carey's (2009, p. 108) contention that the "Brazilian interlude relates directly to slavery since he [Crusoe] needs this source of labour to run his estate". Imaginary creation though it was, Crusoe's story embodies the multifaceted aspects of a historical experience that would define the present and future of this country, as it fictionalises the expeditions that left Brazil destined for Africa in the seventeenth century. As Karen Kuppermann (2015, p. 29) remarks,

The transatlantic slave trade began in earnest with the creation of sugar plantations in Brazil, and the numbers of enslaved Africans carried into lifetime servitude across the Atlantic grew steadily through the seventeenth century. Africans forced into slavery across the ocean constituted two-thirds of the total migration into the Americas between 1600 and 1700 .

Thus, at the onset of Crusoe's twenty-eight-year castaway life on the Caribbean island, on his laborious path to individual and economic autonomy, lies a tale of human trafficking and exploitation, forced labour, and violence, which sustained economic growth and colonial

\footnotetext{
${ }^{1}$ This is Defoe, about English slaveholders in Barbados: "[...] the Negroes are indeed Slaves, and our good People use them like Slaves, or rather like Dogs, but that by the Way: He that keeps them in Subjection, Whips, and Corrects them, in order, to make them grind and labour, does Right, for out of their Labour he gains his Wealth: but he that in his Passion and Cruelty, Maims, Lames, and Kills them, Fool, for they are his Estate, his Stock, his Wealth, and his Prosperity." (DEFOE, 1712, p. 729, italics in the original).
} 
expansion in the second half of the seventeenth century. Royalty itself was implicated in the slave trade with King Charles II and his brother James, Duke of York, having helped establish the Royal African Company in order to control all English business in African slave trading. In a South Atlantic infested with pirate and slave ships, Britain's involvement and participation in the slave trade was not news to Defoe, London and Bristol being the two most important British ports for slavers between the 1660 s and the 1740 s.

Crusoe's lack of moral concern and disregard for the consequences of his slaving activities would not, therefore, appear to be out of place in a context in which commercial gain and supremacy had the upper hand and justified financial adventurism and material drive. As one member of the clergy ${ }^{2}$ claimed,

In a word, the whole earth is the market of Britain; and while we remain at home safe and undisturbed, have all the products and commodities of the eastern and western Indies brought to us in our ships and delivered into our hands (apud DABYDEEN, 1983, p. 2, italics in the original).

With much of its riches deriving from its colonies, England depended on slave labour for the production of its wealth. The slave trade enabled the financial existence of Britain, and its revenue would later help fund the Industrial Revolution. Defoe himself was aware that the slave trade was decisive in Britain's building up as a world power. As he wrote at some point,

The Case is as plain as Cause and Consequence. (...) No African Trade, no Negroes; no Negroes, no Sugars, Gingers, Indicos [indigoes] etc.; no Sugars, etc. no Islands; no Islands, no Continent; no Continent, no trade. (DEFOE, 1711, p. 89, italics in the original).

Generally speaking, slavery was thought to be acceptable and necessary. Some argued at the time that the trade in black people saved them from the tyranny of their own countrymen and from cannibalism, thus excusing it simultaneously on economic and moral grounds. Others blamed the slave trade on the Africans themselves, who they contended

${ }^{2}$ Revd. CATCOTT, A. S. , 1744. 
captured their fellow countrymen and sold them into slavery. As a vigorous supporter of the importance of trade for the 'wealth of nations' in his articles and pamphlets, suppression of slavery was not a cause Defoe ever promoted. In Defoe's practical, unsentimental, down-to-earth view, he shared his contemporaries' stance. However, he also did write on occasion anti-slavery pieces in order to denounce slave traders and their interpretation of Christianity, as he did in his Reformation of Manners (1702). While he felt assured of the white man's right to use black slaves for his own enrichment, he also advocated that their treatment should be benevolent and humane, as he also did in his 1722 novel Colonel Jack. ${ }^{3}$ His connections with the world of commerce seem to be responsible for what we regard as conflicting opinions on the question of slavery and the slave trade. What Hans Andersen (1941) describes as the paradox of trade and morality in Defoe - that is to say, the irreconcilable dilemma between commercial interests and religion - was something the writer was aware of but only to dismiss "the ethical objections" from immediate consideration. On stressing the economic necessity of keeping "negroes" in subjection, he established a sharp cleavage between trade and morality, whereby religion should never be a hindrance to business. Defoe's age came to recognise the split between business and religion and therefore, the separation between religious and secular affairs; the clergy came to interfere less and less in the latter as business tended to become an increasingly independent sphere, an idea promoted by economic theorists.

Thus, it should come as no surprise that in such a thorough examination of matters of conscience as in Robinson Crusoe, in which disobedience and guilt play such an important part, there is no open condemnation of the "practice of racial slavery" (GILROY, 1993, p. 42). The initial sections of the novel locate it within the context of a controversial history, which evokes the extent to which slavery was deeply embedded in the emergence of early modernity and represented the underside of the Enlightenment project, with its promise of freedom and belief in progress.

Crusoe's struggle for survival leaves in the background the fact that the vessel that founders on the unnamed Caribbean island was, in fact, a slave ship. Though punctuated by notions of penitence and redemption during his twenty-eight-year ordeal, his experience as a trafficker and

\footnotetext{
3 "to use them with humanity" (DEFOE, 2015, p. 130).
} 
slaveholder will never bear a moral weight. Quite the contrary, Crusoe's main concern will be his quest for both wealth and social improvement. His shipwreck represents, therefore, the chance of a new beginning, of building a small kingdom from wrecks, where he can accumulate, rule and also submit himself to rigorous moral and religious scrutiny. With the economic, social and intellectual freedom which solitude allows him, he literally rebuilds his life from scratch. On his island, he can live his utopia and imagine he is king and lord, re-creating a surrogate England in it. Like an English "enclosing lord", he takes possession of the land, encloses it and reproduces relations of sovereignty, in the small community formed by Man Friday and the Spanish sailors. It would be difficult to overlook the obvious association the novel implies between the two islands and, therefore, the national allegory involved in Crusoe's re-creation of English life in the tropics, in all its practical, everyday details and ideological dimension.

On a virgin and remote island in the Caribbean, near the mouth of the Orinoco river, an Englishman builds a community whose insularity, miniscule dimensions and socially circumscribed composition would hardly make it unknowable. ${ }^{4}$ However, the ominous presence of the cannibals whom he occasionally encounters and the footprint on the empty beach ${ }^{5}$ confront him with the unknown. There, Robinson Crusoe experiences what Peter Hulme has described as "the paradigmatic colonial encounter, that key scene of colonial literature where the recently rescued Caribbean Amerindian, soon to be named Friday, places his head beneath the foot of a bewildered European" (HULME, 1992, p. 176). In acknowledgement for Crusoe having spared his life, the native

came close to me, and then he kneel'd down again, kiss'd the Ground, and laid his Head upon the Ground, and taking me by the Foot, set my Foot upon his Head; this it seems was in token of swearing to be my Slave for ever (...) (DEFOE, 2008, p. 172).

\footnotetext{
${ }^{4}$ The reference here is to Raymond Williams's concept of 'knowable community', in (WILLIAMS, 1993).

5 'It happen'd one Day about Noon, going towards my Boat, I was exceedingly surpriz'd with the Print of a Man's naked Foot on the Shore, which was very plain to be seen in the Sand; I stood like one Thunder-struck, or as if I had seen an Apparition." (DEFOE, 2008, p. 130).
} 
The re-enactment of the "original encounter between civilization and savagery" (HULME, 1992, p. 187) introduces the colonial question into the province of the novel: Crusoe names Friday, teaches him English and Christianity and enrols him in his service. For the first time in the rising novel genre, the colonial subject speaks. But the language we hear is that of the coloniser. Friday's fluent, yet broken English is the vocal manifestation of his voluntary 'enslavement': Master is the name he learns to call Crusoe. Friday's "signs [...] of subjection, servitude, and submission" (DEFOE, 2008, p. 174) become more than just gestures and bodily movement; rather, they suggest that his adoption of the language of the "civiliser" inscribes the linguistic sign (signifier and signified) in the processes of domestication and social domination integral to the colonial enterprise in the New World.

The education of the native and Crusoe's gift to him of the conqueror's language substantiate the powerful system of subjugation which constitutes the Aufklärung and the exercise of forms of control and power that it implies. Enlightenment, as Adorno and Horkheimer (2002) have clearly demonstrated, contains its own negation, revealing the grim side of the project of human emancipation. Robinson Crusoe is at the heart of this issue. Adorno and Horkheimer's references to Robinson Crusoe in Excursus I ("Odysseus or Myth and Enlightenment"), where Defoe's protagonist is connected to the Homeric hero, undoubtedly have fed Ian Watt's considerations about the character he would discuss on several occasions: in an article published in Essays in Criticism in 1951, in "Defoe as Novelist" (1957), in a chapter of The Rise of the Novel (1957) and in the essay in Myths of Modern Individualism (1994) which to some extent retrieves and revises some ideas discussed in the 1951 article. Over and above the wanderings and the adventurous life of both heroes, the association between them, which Adorno and Horkheimer suggest at intervals, are related to the problem of the constitution of the individual and the cost of self-mastery in an adverse and inhuman world, ruled by mythical and/or natural forces.

To probe the possible connections sensed by Watt, it may be useful to resort to a comment made by Jeanne Marie Gagnebin (2006, p. 13) about Adorno and Horkheimer's reading of Ulysses' travels:

Adorno and Horkheimer have found in the Odyssey the description of the paradigmatic constructions of the rational subject who, in order to construct himself as sovereign 'I', must escape the 
temptations and seductions of myth, ensuring his domination over external nature and also over internal nature, over himself.

If, as Gagnebin (2006, p. 13), sums it up, from the perspective of the authors of Dialectic, Ulysses' saga "represents [...] the formation of the subject through domination over nature and self-repression", its resonances with Robinson Crusoe soon make themselves heard. Not only is this a problem which is at the core of the modern novel but Daniel Defoe stages it exemplarily in the narrative of the young man who leaves his home and faces the unknown in search of adventure and social advancement. The gods no longer control his destiny, even though Providence (frequently invoked) is made responsible for the success and also for the failures of his undertaking, in accordance with the Puritan tradition of interpreting life incidents as signs of divine intention or intervention (WATT, 2002 p. 97).

To confront helplessness and preserve his human condition in risky situations, the castaway makes use of rational control and cunning, in the arduous task of surviving and overcoming the dangers and challenges he is subjected to in the course of his adventures. Like Ulysses, in a state of "absolute loneliness" (HORKHEIMER; ADORNO, 2002, p. 49), Crusoe avails himself of instrumental reason to dominate nature and build a minimal structure of subsistence on the desert island. To conquer the environment, the English sailor depends on rational planning and calculation, as well as pragmatic and utilitarian actions which end up recreating a miniature England in this new space, where he is lord and king. His instinct of self-preservation triggers and mobilises all his skills and makes him reason, ponder each step he takes and each measure he adopts - rationality guides and leads him in the daily tasks necessary for the reproduction of life:

(...) as Reason is the Substance and Original of the Mathematicks, so by stating and squaring every thing by Reason, and by making the most rational Judgment of things, every Man may be in time Master of every mechanick Art. I had never handled a Tool in my Life, and yet in time, by Labour, Application, and Contrivance, I found at last that I wanted nothing but I could have made it, especially if I had had Tools; (...) (DEFOE, 2008, p. 85).

Thus, the several operations needed for his survival (cooking, making garments, planting, harvesting, etc.) and their results are 
described in detail - Crusoe calculates, takes notes, gives explanations and fills the narrative with those particularities that incorporate into the novel "the circumstantial view of life" that Ian Watt implied in his formulation of "formal realism"'. As Watt (1997, p. 158) points out, this process of production of the minimal conditions of existence reproduces the different stages in human history - collecting, hunting, fishing, pastoral and agricultural activities - and introduces "the rationality of the processes of economic life" on the desert island (WATT, 1951, p. 100). Crusoe's determination and perseverance in imposing some order on his daily routine, managing his time, organising his existence and, above all, turning the adverse conditions in his favour make him "a triumph of human achievement and enterprise" (WATT, 1951, p. 97). The primordial aim of profit, utilitarianism, the commodification of human relations - everything justifies the phrase homo economicus attributed to him. The epitome of the capitalist entrepreneur, the embodiment of economic individualism, however we describe him, Crusoe has become a mythical figure, in so far as he has symbolized some of the fundamental values of a changing society and a rising social class, taking on a central role in the construction of the meaning of modern individualism.

Crusoe illustrates the rise of the modern subject and his location in historically very complex configurations. The confrontation of great trials, on the one hand, and his separation from his fellow men, on the other, are the price he pays for his formation as an individual. To the break of familial ties, with his leaving home, there follows a succession of episodes in which Crusoe systematically dismisses all the bonds life offers him in favour of his domination over those who cross his path. Thus, he treats Xury as a commodity, selling him to the Portuguese captain, after the Moorish boy helped him in his escape and Atlantic crossing. With the native he finds after twenty five years of isolation on the island, it is no different: instead of a friend, Crusoe makes Friday his "slave". He names him, teaches him his own language, and recruits him into his service. In his disagreement with this interpretation, Daniel Carey (2009, p. 123) argues that Friday's position is that of a subject since the island is Crusoe's private property:

In fashioning himself as a monarch, Crusoe establishes the role they [Friday, the Spaniard, and Old Friday] occupy. [...] He [Friday] is not a slave but a subject, under the authority of a master whose political power is absolute. As a subject, he may owe his 
service but he is not held as property; his condition is voluntary since he is free to leave.

While Carey (2009, p. 123) is right in pointing out that Crusoe establishes a "patriarchal system of rule" in which relations of dependence and patronage obtain, he overlooks the fact that Crusoe's is a first-person narrative, by definition an unreliable account that allows for his point of view exclusively, and gives him the prerogative of determining what to tell and how to tell it. It is his own perspective that prevails and some mistrust of the truth of his words seems to be necessary and relevant. The very ambiguity embodied in Crusoe's use of the verb "subject"' should caution us against cancelling out reading the relationship between Crusoe and Friday as that of master and slave, as well as, as Carey (2009, p. 128) would have it, "father and son, master and servant, teacher and pupil, monarch and subject". It is true that Crusoe never calls Friday a slave, but for Hulme (1992, p. 205) "that absence is merely a symptom of the constant process of denial and renegotiation by which the text attempts to redraw the colonial encounter". For Defoe (apud ARAVAMUDAN, 2009, p. 52), the mission of the English colonist was to

civilize and instruct the Savages and Natives of those Countries wherever they plant, so as to bring them by the softest and gentlest Methods to fall into the Customs and Usage of their own Country, and incorporate among our People as one Nation.

As a Carib native, and therefore pagan, Friday will also be catechized in order to lay "a foundation of religious knowledge in his mind":

[...] I began to instruct him in the Knowledge of the true God: I told him that the great Maker of all Things liv'd up there, pointing up towards Heaven: That he governs the World by the same Power and Providence by which he had made it; That he was omnipotent, could do every Thing for us, give every Thing to us, take every Thing from us; and thus by Degrees I open'd his Eyes. (DEFOE, 2008, p. 182)

\footnotetext{
${ }^{6}$ Shorter Oxford English Dictionary: "1. Cause or force someone or something to undergo (a particular experience or form of treatment, typically an unwelcome or unpleasant one); 2. Bring (a person or country) under one's control or jurisdiction, typically by using force." (SUBJECT, v. 2, 2007).
} 
Colonisation was also about converting heathens to Christianity. On recreating a substitute kingdom on the island, Crusoe applies all the tenets that guided colonisers in their mission to introduce the natives into religious notions and practices. Crusoe teaches Friday some basic principles and instructs him on God, the Devil, evil, Providence, etc. More importantly, as a converted Protestant, Crusoe seems to see himself as saving this native from Catholicism as well as savagery, thus re-enacting the British stance in its opposition to Catholic Spain. References to "priestcraft" and the Inquisition in his narrative suggest Crusoe's anxiety over matters of faith, while he feels sure "liberty of conscience" and tolerance are prerogatives expressly associated with his religious affiliation.

"Commerce"- which means trade, business, but also social dealings between people - seems to be the ideal word to describe the nature of the ties that Crusoe establishes with his fellow human beings. His is an essentially lonely existence, one that excludes familial relations, friendship, love, since even his marriage and children are reduced to a few lines in his account as if they were mere accidents and not important events in the private sphere. Reflecting in retrospect about his life on the island, in the last book of the trilogy, Crusoe offers us a meditation on solitude. There, he makes a few notes about this human condition, which he experienced for so long and so inescapably:

\begin{abstract}
What are the Sorrows of other Men to us? And what their Joy? Something we may be touch'd indeed with, by the Power of Sympathy, and a secret Turn of the Affections; but all the solid Reflection is directed to our selves. Our Meditations are all Solitude in Perfection; our Passions are all exercised in Retirement; we love, we hate, we covet, we enjoy, all in Privacy and Solitude: All that we communicate of those Things to any other, is but for their Assistance in the Pursuit of our Desires; the End is at Home; the Enjoyment, the Contemplation, is all Solitude and Retirement; 'tis for our selves we enjoy, and for our selves we suffer (DEFOE, 1720, p. 2-3).
\end{abstract}

It does not seem difficult to understand why Crusoe has become one of the myths of modern individualism and why his personal epic has acquired the status of an emblematic narrative in a crucial moment in the history of the constitution of the bourgeois world. His odyssey embodied the dilemmas and values of a society about to establish it as a model and ideal for its citizens. 
Robinson's encounter with and subjection of Friday on the island is just the last stage of his long-standing involvement with the commercial aspects of colonisation and its engagement with the slave trade. As Laura Doyle (2009, p. 14) indicates, "Defoe's text registers the pivotal role of slavery in Crusoe's Atlantic adventures": from the very beginning, Robinson had been set on becoming "a Guiney trader", had shown no remorse for selling Xury to the Portuguese captain, even if he had experienced captivity himself at Salé, and had shipwrecked on his way to buy slaves for his Brazilian plantation. Though he recognises slavery as the lowest imaginable condition for a Christian like himself, he does not hesitate to engage in the pursuit of profit even if at the expense of his fellow human beings. Robinson's introjection of his national culture and its ideology explains his actions and choices and preserves his identity as an English national wherever he is or whatever he does. He is not changed by this encounter with the "other"; rather, every situation serves to confirm his identity as a colonial adventurer for whom colonialism entails a very clear commercial meaning. The national, therefore, is contained within the transnational in this narrative, which embodies both spheres and is prophetic of the empire, as a very perceptive young James Joyce realised:

The true symbol of the British conquest is Robinson Crusoe, who, cast away on a desert island, in his pocket a knife and a pipe, becomes an architect, a carpenter, a knife grinder, an astronomer, a backer, a shipwright, a potter, a saddler, a farmer, a tailor, an umbrella-maker, and a clergyman. He is the true prototype of the British colonist, as Friday (the trusty savage who arrives on an unlucky day) is the symbol of the subject races. The whole Anglo-Saxon spirit is in Crusoe: the manly independence; the unconscious cruelty; the persistence; the slow yet efficient intelligence; the sexual apathy; the practical, well-balanced religiousness; the calculating taciturnity. Whoever rereads this simple, moving book in the light of subsequent history cannot help but fall under its prophetic spell. (JOYCE, 1994, p. 323)

\footnotetext{
${ }^{7}$ One should not forget that Defoe was a shareholder in the Royal African Company and defended the slave trade.

${ }^{8}$ Lecture delivered at the Università Popolare Triestina (Trieste, Italy), March 1912.
} 
Joyce did not make the connection between colonialism and imperialism and slavery, though he does mention "subject races". But it was the economic activity, which included here that of subjecting other peoples and trading them, that was at the root of the accumulation of capital which would produce empires. Like capital, it was an activity which knew no boundaries and respected no real or imaginary limits or borders. Though supreme ruler on his island, it was Crusoe's Brazilian plantation that made him a wealthy man, with the help of an indentured servant and a black slave. For all the time Crusoe is stranded on the island his plantation prospers, having become a sugar plantation ("engenho"), a slave-based estate "of above a thousand pounds a year" which Crusoe's partner describes thus in a letter to him:

There was a Letter of my Partner's, congratulating me very affectionately upon my being alive, giving me an account how the Estate was improv'd, and what it produced a Year, with a Particular of the Number of Squares or Acres that it contained; how planted, how many slaves there were upon it, $[\ldots]$

By the same Fleet, my two Merchant Trustees shipp'd me 1200 Chests of Sugar, 800 Rolls of Tobacco, and the rest of the whole Accompt in Gold. (DEFOE, 2008, p. 239)

Trade in goods and people was the engine that drove the system and funded the Industrial Revolution later in the century. A tradesman himself, Defoe was an inveterate advocate of overseas trade, which he continually wrote about in his journals. ${ }^{9}$ In his defence of self-interest and profit, in one of his articles in Mercator, he lifts all bans and establishes no boundaries, be they political, religious or geographical:

We know no Parties in Commerce, no Alliances, no Enemies; they are our Friends we can Trade with to Advantage, tho' otherwise hating us and hated by us; no Differences of State-Matters are concerned here; we know no Whig or TORY in Trade: There is no Popery in Commerce; it matters not to use what God they worship, what Religion they own, with whom we Trade; our Commerce worships but one Idol, viz. GAIN; we trade with Mahometans in Turkey, Pagans in India, Savages in Africa, Papists in Spain,

\footnotetext{
${ }^{9}$ In the last issue of his Review, he would set down: "Writing upon Trade was the Whore I really doated upon." (DEFOE, 1713, p. 214).
} 
Italy and France, and nearer home with Jews, Christians, and Hollanders. (DEFOE, 1714, p. 155, italics in the original)

The promotion of free trade on a global scale seemed to be one of Defoe's concerns. It is not difficult, therefore, to understand his involvement with the South Sea Company (in the Pacific Ocean) and investment in the Royal African Company. He defended a monopoly in the case of the latter since he believed that this would lower the prices of the slaves that were necessary for the plantations in the Americas. Africans, in their turn, Defoe (apud ARAVAMUDAN, 2009, p. 56) deemed to be "unpolish'd, vile, and degenerate, 'brutal, savage, untractable",, and willing to "barter Baubles for the Souls of Men". Defoe's economic and political ideas would, therefore, percolate through his fiction, with the sea as the vast expanse that for him "seems [...] to be the great Common of all the Creation; all have a right to Range in it; none have an Exclusive Property to any part of it; [...]" (DEFOE, 1711, p. 50). In tandem with Great Britain's role as a maritime and commercial power, Defoe's fiction features adventure stories as a "means of diagnosing global positioning for national domestic advantage" (ARAVAMUDAN, 2009, p. 45).

Although Crusoe's adventures in the Atlantic take place in the seventeenth century, the issues it raises and its economic and political background are very much related to matters of interest in Defoe's own present, as reading Robinson Crusoe in the light of Defoe's journalism demonstrates. His support of the South Sea Company, a joint venture that had the monopoly of supplying African slaves to the islands in the South Seas and to South America, is telling proof that the Brazilian episode is no sheer accident in the structure of the novel. Rather, together with the other previous events involving slaving-ships, trade with Africa, piracy (all in the pre-island section), Crusoe's Brazilian experience as a planter, trader, and slaver is intrinsically entangled in the issues which Defoe engaged in. As Claire Gallien (2019, p. 141) remarks, in Robinson Crusoe "Africa is present in South America, and the free circulation of goods under capitalism necessitates the exploitation of nature and men on the plantation."

The transatlantic slave trade was, in the words of the African American scholar and activist W.E.B. Du Bois, "the most magnificent drama in the last thousand years of human history". For him, it was rather an absolute tragedy: "the transportation of ten million human beings out of 
the dark beauty of their mother continent into the new found El Dorado of the West. They descended into Hell" (apud MOHAMUD; WHITBURN, 2018). Crusoe's thirst for personal and social advancement, his trust in trade, his unconcern for the commodification of African bodies bring him to the South Atlantic, a crossroads of three continents enmeshed in one of the most deplorable chapters in the history of a period of enormous global change.

\section{References}

ANDERSEN, Hans H. The Paradox of Trade and Morality in Defoe. Modern Philology, Chicago, v. 39, n. 1, p. 23-46, Aug. 1941. DOI: https:// doi.org/10.1086/388504

ARAVAMUDAN, Srinivas. Defoe, Commerce, and Empire. In: RICHETTI, John (ed.). The Cambridge Companion to Daniel Defoe. Cambridge: Cambridge University Press, 2009. p. 45-63. DOI: https:// doi.org/10.1017/CCOL9780521858403.004

CATCOTT, A. S. The Antiquity and Honourableness of the Practice of Merchandize: a Sermon. Bristol: [S. n.], 1744.

CAREY, Daniel. Reading Contrapuntally. Robinson Crusoe, Slavery, and Postcolonial theory. In: CAREY, Daniel and FESTA, Lynn (ed.). The Postcolonial Enlightenment: Eighteenth-Century Colonialism and Postcolonial Theory. Oxford: Oxford University Press, 2009. p. 105-136. DOI: https://doi.org/10.1093/acprof:osobl/9780199677597.003.0004.

DABYDEEN, David. Commerce and Slavery in Eighteenth-Century Literature. Kunapipi, Wollongong, v. 5, n. 2, p. 2-23, 1983.

DEFOE, Daniel. A Brief Account of the Present State of African Trade. In: MCVEAGH, John (ed.). Trade. London: Pickering \& Chatto, 2000. p. 57-82. (Political and economic writings of Daniel Defoe, 7).

DEFOE, Daniel. A General History of Trade. London: J. Baker, 1713.

DEFOE, Daniel. Colonel Jack. Ontario: Broadview Press, 2015.

DEFOE, Daniel. Mercator: or, Commerce Retrieved. London: [s.l.], 1713-1714. 
DEFOE, Daniel. Moll Flanders. New York; London: W.W. Norton \& Company, 1973.

DEFOE, Daniel. Of solitude. In: DEFOE, Daniel. Serious Reflections During the Life and Surprising Adventures of Robinson Crusoe: with his Vision of the Angelick World. Written by Himself. London: Printed for W. Taylor, 1720. p. 2-3.

DEFOE, Daniel. Review. London: [s.l.], 1704-1713. 9 v.

DEFOE, Daniel. Robinson Crusoe. Oxford: Oxford University Press, 2008. DOI: https://doi.org/10.1093/owc/9780199553976.001.0001

DOYLE, Laura. Toward a Philosophy of Transnationalism. Journal of Transnational American Studies, Santa Bárbara, CA, v. 1, n. 1, p. 1-29, 2009. DOI: https://doi.org/10.5070/T811006941

FREITAS Marcus Vinicius. The Image of Brazil in Robinson Crusoe. In: ROCHA, João Cezar de Castro. Brazil 2001: A Revisionary History of Brazilian Literature and Culture. Dartmouth: University of Massachusetts Press, 2000. p. 453-459. (Portuguese Literary and Cultural Studies, 4/5).

GAGNEBIN, Jeanne Marie. A memória dos mortais: notas para uma definição de cultura a partir de uma leitura da Odisséia. In: GAGNEBIN, Jeanne Marie. Lembrar escrever esquecer. São Paulo: Editora 34, 2006. p. 13-27.

GALLIEN, Claire. Of Seas, Slaves, and Colonies in Robinson Crusoe Cartography, Strata, and Contrapuntal Reading. Études Anglaises, Paris, v. 72, n. 2, p. 135-150, Avr.-Juin 2019. DOI: https://doi.org/10.3917/ etan. 722.0135

GILROY, Paul. The black Atlantic: Modernity and Double Consciousness. Cambridge: Harvard University Press, 1993.

HORKHEIMER, Max; ADORNO, Theodor W. Dialectic of Enlightenment. Translation by Edmund Jephcott. Stanford: Stanford University Press, 2002.

HULME, Peter. Robinson Crusoe and Friday. In: HULME, Peter. Colonial Encounters: Europe and the Native Caribbean, 1492-1797. London: Routledge, 1992. p. 175-222. 
JOYCE, James. Daniel Defoe, Lecture Delivered at the Università Popolare Triestina (Trieste, Italy), March 1912. In: DEFOE, Daniel. Robinson Crusoe. Edited by Michael Shinagel. New York; London: W.W. Norton, 1994. p. 323.

KEANE, Patrick J. Slavery and the Slave Trade: Crusoe as Defoe's Representative. In: LUND, Roger D. (ed.). Critical essays on Daniel Defoe. New York: G.K. Hall; London: Prentice-Hall, 1997.

KUPPERMANN, Karen Ordahl. The Seventeenth Century. Expansion and Consolidation. In: MILLER, Joseph C. et al. (ed.). The Princeton Companion to Atlantic History. Princeton: Princeton University Press, 2015. DOI: https://doi.org/10.1515/9781400852215.

MILLER, Joseph C. (ed.). The Princeton Companion to Atlantic history. Princeton: Princeton University Press, 2015.

LINDSAY, Jack. The Monster City: Defoe's London, 1688-1730. London: Granada, 1978.

MACINELLY, Brett C. Expanding Empires, Expanding Selves: Colonialism, The Novel, and Robinson Crusoe. Studies in the Novel, Denton, v. 35, n. 1, p. 1-21, Spring 2003.

MOHAMUD, Abdul; WHITBURN, Robin. Britain's Involvement with New World Slavery and the Transatlantic Slave Trade. Discovering Literature, London, 21 Jun. 2018. Articles. Available at: https://www. bl.uk/restoration-18th-century-literature/articles/britains-involvementwith-new-world-slavery-and-the-transatlantic-slave-trade. Access: 10 Sept. 2019.

PRADO, Raquel de Almeida. Do 'Brasil' de Rousseau ao 'Brasil' de Defoe: indivíduo e Novo Mundo. Rapsódia, São Paulo, n. 1, p. 17-22, dez. 2001.

WATT, Ian. Defoe as Novelist. In: WATT, Ian. The Liberal Imagination: Selected Essays. Edited by Bruce Thompson. Palo Alto: The society for the promotion of science and scholarship; Stanford: The Stanford humanities center, 2002. p. 92-105.

WATT, Ian. Myths of Modern Individualism: Faust, Don Quixote, Don Juan, Robinson Crusoe. Cambridge: Cambridge University Press, 1997. DOI: https://doi.org/10.1017/CBO9780511549236 
WATT, Ian. Robinson Crusoe as a Myth. Essays in criticism, Oxford, v. 1, n. 2, p. 95-119, Apr. 1951. DOI: https://doi.org/10.1093/eic/I.2.95 WATT, Ian. The Rise of the Novel: Studies in Defoe, Richardson and Fielding. Harmondsworth: Penguin, 1983.

WILLIAMS, Raymond. The Country and the City. London: The Hogarth Press, 1993.

Recebido em: 10 de novembro de 2020. Aprovado em: 29 de abril de 2021. 
